\title{
Benjamin e Brecht: a pedagogia do gesto
}

\author{
$\frac{\text { Luciano GATTI }}{\text { Doutor em filosofia pela Unicamp }}$
}

Resumo: $O$ artigo examina a interpretação do teatro épico de Bertolt Brecht elaborada por Walter Benjamin em seu ensaio "O que é o teatro épico?”, de 1931. A partir da exigência de reconfiguração crítica do teatro tradicional, em vista do esclarecimento do público e de sua vinculação a um movimento mais amplo de transformação social, são apresentados os pressupostos e as dificuldades de um teatro pedagógico, tal como apresentado por Brecht em sua peça Um homem é um homem. Com isso, discute-se a perspectiva de análise de Benjamin, que ressalta o potencial crítico e anti-ilusionista de certos procedimentos teatrais, notadamente a produção de gestos pela interrupção da ação.

Palavras-chave: Walter Benjamin, Bertolt Brecht, teatro épico.
Abstract: The paper analyses the interpretation of Bertolt Brecht's epic theatre elaborated by Walter Benjamin in his essay "What is epic theatre?" (1931). After pointing out the demand of critical reconfiguration of the traditional theatre in view of the instruction of the public and of his association to a broader movement of social transformation, the difficulties and presuppositions of a pedagogical theatre, so as it is presented by Brecht in his play $A$ man is a man, are presented. Benjamin's perspective of analysis is then finally discussed, particularly its emphasis on the critical and ant-illusionistic potential of theatrical proceedings such as the production of gestures by the interruption of action.

Key-words: Walter Benjamin, Bertolt Brecht, epic theatre.

\section{Preâmbulo}

A exigência político-artística de transformação das condições de produção e recepção artísticas, de modo que o teatro pudesse exercer algum papel no processo de esclarecimento do público, orienta os esforços de Bertolt Brecht durante os anos de colaboração intelectual com Walter Benjamin. Esta exigência se traduz numa concepção pedagógica do trabalho artístico e da obra de arte, bem como na crítica às obras e às concepções estéticas, antigas ou contemporâneas, aquém desta exigência. Os pressupos- 
tos e as dificuldades da posição de Brecht, bem como as reservas de Benjamin em relação a ela, vieram à tona nas discussões entre ambos durante a estadia de verão de 1934 na casa de Brecht em Svendborg, Dinamarca, a respeito da interpretação da parábola kafkiana, cuja dificuldade provocava o mal-estar de um Brecht preocupado com a clareza e inteligibilidade do ensinamento sobre a realidade a ser produzido e transmitido pela arte. ${ }^{1}$ Heiner Müller fornece uma interessante introdução a esse problema:

Kafka faz parte dos diálogos de Svendborg entre Brecht e Benjamin. Nas entrelinhas de Benjamin surge a questão de saber se a parábola kafkiana não é mais ampla e capaz de compreender a realidade do que a parábola de Brecht. Aquela representaria gestos sem sistema referencial e não é orientada por uma práxis, irredutível a um significado, antes estranha que alienante, sem moral. ${ }^{2}$

A fonte da divergência apontada por Müller se encontra na interpretação da parábola kafkiana fornecida por Benjamin em seu ensaio "Franz Kafka. A propósito do décimo aniversário de sua morte" (1934). De acordo com Benjamin, as parábolas de Kafka apresentam uma subversão dessa forma narrativa. Tradicionalmente, ela estava associada à transmissão de uma doutrina, apresentada como ensinamento dirigido à vida prática. Seu sucesso como mediação entre a doutrina e a ação pressupunha, assim, a efetividade da autoridade cristalizada nessa doutrina, fosse ela de origem religiosa ou tradicional. A parábola de Kafka se constituía, contudo, como o paradoxo de uma parábola sem doutrina, o que era explicado por Benjamin pelo fato de elas figurarem o desmoronamento da doutrina judaica que conferia sentido à interpretação do ensinamento contido nos textos sagrados. $\mathrm{Na}$ ausência dessa chave de leitura que vinculava

1. As discussões foram documentadas pelo próprio Benjamin na forma de diário. Cf. Benjamin, W. "Notizen Svendborg Sommer 1934". In: Gesammelte Schriften, vol. VI. Frankfurt am Main: Suhrkamp, 1999, pp. 525-30.

2. Müller, H. "Fatzer \pm Keuner”. In: Koudela, I. (org.). O espanto no teatro. São Paulo: Perspectiva, 2003, p. 50. 
os textos à verdade fundada na doutrina, Kafka transformara a parábola em um enigma indecifrável.

O desacordo de Brecht surge dessa intraduzibilidade da parábola em ensinamento. Se, para Benjamin, Kafka teria tido o mérito de mostrar o declínio de uma concepção de verdade calcada na tradição, Brecht interpreta a indecifrabilidade da parábola kafkiana como uma imperfeição e, nesse sentido, como índice do fracasso de Kafka como escritor. "Essa parábola, diz Brecht a Benjamin, (...) nunca foi inteiramente transparente". ${ }^{3}$ A valorização dessa forma por Benjamin é, consequentemente, tachada por Brecht de obscurantismo, como se Benjamin tivesse cedido à "estéril profundidade" que marcaria parte da obra de Kafka. Este teria apresentado imagens interessantes da alienação e da burocracia da sociedade contemporânea, mas não teria extraído delas nenhum ensinamento para a vida prática. Sua falta de clareza, diz o iluminista Brecht, poderia prestar-se, inclusive, à apropriação pelo fascismo. ${ }^{4}$ Diante disto, Brecht propõe uma outra perspectiva para a leitura de Kafka, que ele apresenta, não por acaso, na forma de uma parábola.

Numa floresta, há troncos de diversos tipos. Os mais grossos servem à produção de vigas para a produção de navios. Os menos sólidos, mas ainda assim consideráveis, servem para tampas de caixas e paredes de caixão. Os bem finos são utilizados como açoites. Já os deformados não servem para nada - eles escapam ao sofrimento da utilidade. Devemos olhar o que Kafka escreveu como olhamos essa floresta. Encontraremos uma quantidade de coisas bem úteis. As imagens são boas. $\mathrm{O}$ resto não passa de mania de segredos. É um disparate. Devemos deixar isso de lado. Com a profundidade não

3. Benjamin, W. "Notizen Svendborg Sommer 1934”. In: Gesammelte Schriften, vol. VI, p. 525.

4. Cf. a seguinte passagem de uma das conversas com Brecht: "Deveríamos imaginar uma conversa de Lao Tsé com o estudante Kafka. Lao Tsé: Então, estudante Kafka, as formas da economia e da organização social em que você vive tornaram-se estranhas para você? - Kafka: Sim. - Lao Tsé: Você não consegue mais se orientar nelas? - Kafka: não. - Lao Tsé: As ações de uma empresa na bolsa são algo estranho para você? Kafka: Sim - Lao Tsé: Então, estudante Kakfa, você exige agora um líder ao qual você possa recorrer. - Brecht, continuando: Isto é certamente condenável. Eu me recuso a aceitar Kafka”. Idem, p. 527. 
se vai longe. Ela é uma dimensão que se basta a si mesma. A mera profundidade - daí não sai nada. ${ }^{5}$

Esse texto ilumina mais a tarefa cobrada por Brecht da literatura, bem como seu mal-estar diante da obra de Kafka, do que o próprio teor da obra do escritor tcheco. Ele não realiza uma análise literária das narrativas, nem transforma em questão a dificuldade de interpretação, mas procura liquidar o enigma ao transformá-lo em uma alegoria do mundo atual. É desta perspectiva que Brecht justifica uma interpretação de $O$ Processo como alegoria profética, seja das mediações invisíveis que determinam a vida dos homens nas grandes cidades, seja da ascensão do fascismo.

As objeções de Brecht à resistência da parábola kafkiana à transmissibilidade do sentido, bem como seu esforço em dela extrair um ensinamento por meio da interpretação alegórica, fundam-se na defesa racionalista da força do esclarecimento contra o perigo de recaída do público no ilusionismo propagado pelos regimes fascistas. Na luta contra o fascismo, o teatro e a literatura poderiam desempenhar a função de esclarecimento a respeito das forças que atuam nos processos históricos. Como reconhece Benjamin, "esse esforço crônico de Brecht em legitimar a arte em face do entendimento termina sempre por levá-lo à parábola” ${ }^{6}$ Essa preocupação é extremamente forte numa época em que Brecht estava particularmente preocupado com o alcance didático de seu trabalho e procurava, por meio de considerações de âmbito filosófico-científico, incorporar o problema da luta de classes à sua produção. Nas palavras de Benjamin, tratava-se de "mobilizar a autoridade do marxismo para si” “a partir do próprio teor dogmático e teórico da poesia didática”. ${ }^{7}$ Estas intenções racionalistas de sua produção são desenvolvidas no contexto de sua crítica ao teatro tradicional, chamado por ele de aristotélico, fundado na empatia ou identificação afetiva (Einfüblung) entre o público e o palco e que "através da catarse, da purgação dos

5. Idem, pp. 527-8.

6. Idem, p. 531.

7. Idem, ibidem. 
afetos, ajuda os homens a reencontrar o equilíbrio diante da natureza eterna e imutável das coisas humanas". ${ }^{8}$ Com isso, Brecht confere ao teatro a função de crítica filosófica dos mecanismos ilusionistas da arte.

É significativo que um dos capítulos de seu trabalho teórico Sobre uma dramaturgia não-aristotélica, texto contemporâneo às discussões com Benjamin, leve o título de "O filósofo no teatro". Brecht se vale da figura do filósofo para ressaltar o papel de professor do novo dramaturgo: ele é aquele que ensina que "os processos por trás dos processos são processos entre homens", ou seja, que a história não é um destino, mas resulta da ação conjunta dos homens e, portanto, pode ser sempre transformada. Nesse contexto, o teatro assume a função de despertar no público o interesse do filósofo no comportamento prático dos homens.

Eles [os filósofos] não colecionam apenas as reações dos homens diante de seu destino, mas atacam este destino mesmo. Eles descrevem as reações dos homens do ponto de vista em que elas podem ser compreendidas como ações. $\mathrm{O}$ destino mesmo, contudo, eles o descrevem como uma atividade dos homens. Os processos por trás dos processos que determinam o destino (...). O objeto da exposição é assim o entrelaçamento das relações sociais entre os homens. ${ }^{9}$

É possível entender então por que a valorização por Benjamin da intraduzibilidade da parábola kafkiana em ensinamento é inaceitável para Brecht. Certamente Brecht não estava interessado em colocar sua produção a serviço do ensinamento de uma doutrina tradicional, mas da "autoridade do marxismo", o qual ensinava a possibilidade de transformação social enquanto superação da sociedade de classes.

8. Schwarz, R. "Altos e Baixos da Atualidade de Brecht". In: Seqüências Brasileiras. São Paulo: Companhia das Letras, 1999, p. 114.

9. Brecht, B. Schriften zur Theater, vol. 1. Frankfurt am Main: Suhrkamp, 1967, pp. 256-7. 
As restrições de Benjamin à vinculação por Brecht da função pedagógica de seu teatro aos elementos mais racionalistas da parábola já podiam ser notadas três anos antes, em seu ensaio do início de 1931, “O que é o teatro épico?”, escrito em Berlim em circunstâncias históricas e políticas bem diversas daquelas de 1934. O ensaio corresponde a um esforço de elucidação e defesa do teatro de Brecht perante as severas críticas dirigidas contra a montagem de Um homem é um homem em fevereiro daquele mesmo ano. Apesar dessa circunstância, que impede que o ensaio de Benjamin seja inteiramente reconduzido ao texto da peça, ele não é uma mera "crítica de teatro" jornalística. Ao contrário, na análise dessa montagem ele desenvolve um estudo aprofundado sobre as transformações decisivas introduzidas por Brecht no aparelho teatral com o intuito de conectá-lo a um movimento mais amplo de transformação social. ${ }^{10} \mathrm{~A}$ crítica de concepções herdadas da tradição se torna assim um elemento central do trabalho de Brecht em Um homem é um homem. Nesse sentido, vale aqui a caracterização da fábula da peça feita por Anatol Rosenfeld:

a despersonalização do indivíduo, a sua desmontagem e remontagem em outra personalidade; trata-se de uma sátira à concepção liberalista do desenvolvimento autônomo da personalidade humana e ao drama tradicional que costuma ter por herói um indivíduo forte, de caráter definido, imutável. A concepção épica desta peça liga-se, pois, a uma filosofia que já não considera a personalidade humana como autônoma e lhe nega a posição central. ${ }^{11}$

10. Apesar de tomar parte num esforço conjunto de defesa e explicação do teatro épico, Benjamin não conseguiu publicar seu ensaio. Apenas uma segunda versão, sensivelmente alterada, seria publicada em 1939. A respeito de suas tentativas mal-sucedidas de publicar o texto na imprensa alemã, cf. Wizisla, E. Benjamin und Brecht. Die Geschichte einer Freundschaft. Frankfurt am Main: Suhrkamp, 2004, pp. 182-6. O livro de Wizisla reconstrói com precisão muitos elementos históricos e biográficos referentes à colaboração intelectual entre Benjamin e Brecht, mas, infelizmente, dá pouca atenção à análise mesma dos escritos de Benjamin sobre Brecht.

11. Rosenfeld, A. O Teatro Épico. São Paulo: Perspectiva, 2002, p. 146. 
Nessa peça, que Benjamin ressalta como um primeiro modelo do teatro épico ${ }^{12}$, Brecht conta a história do estivador Galy Gay, apresentado do seguinte modo por Benjamin:

o trabalhador sábio e solitário, [que] concorda com a abolição de sua própria sabedoria e com sua incorporação ao exército colonial inglês. Ele tinha acabado de sair de casa, a pedido da mulher, para comprar um peixe. Nesse momento, encontra um pelotão do exército anglo-indiano, que ao saquear um pagode tinha perdido o quarto homem, que pertencia ao grupo. Os outros três têm todo o interesse em encontrar um substituto o mais rapidamente possível. Galy Gay é o homem que não sabe dizer não. Acompanha os três sem saber o que querem dele. Pouco a pouco, assume os pensamentos, atitudes e hábitos que um homem deve ter na guerra. É completamente remontado, não reconhece a mulher quando ela consegue encontrálo, e acaba transformando-se num temido guerreiro e conquistador da fortaleza Sir el Dchowr, nas montanhas do Tibete. Um homem é um homem, um estivador é um mercenário. ${ }^{13}$

Brecht queria ensinar ao público que o homem não é uma essência fixa e imutável, mas um ser histórico que exerce uma função social correspondente à sua inscrição histórica. $\mathrm{O}$ homem troca de personalidade como o ator troca de papel, desempenhando aquele que é o mais adequado a cada situação. A compreensão das relações sociais como históricas exige a historicização mesma do homem: "Um homem é um homem: não se trata de fidelidade à sua própria essência, e sim da disposição constante para receber uma nova essência". ${ }^{14}$

Benjamin tomou conhecimento da peça pela montagem de 1931, no Staatstheater de Berlim, a qual correspondia à terceira fase de trabalho de Brecht em torno de Um homem é um homem. Os primeiros fragmentos de uma peça que levaria o título de Galgei

12. Benjamin, W. "O que é o teatro épico?". In: __. Gesammelte Schriften, vol. II-2, p. 521. Edição brasileira: Benjamin, W. Obras Escolbidas, vol. I. Trad. de Sérgio Paulo Rouanet. São Paulo: Brasiliense, 1995, p. 80.

13. Benjamin, W. "O que é o teatro épico?”. In:__. Gesammelte Schriften, vol. II-2, p. 526. Edição brasileira: Benjamin, W. Obras Escolbidas, vol. I, pp. 85-6.

14. Idem, p. 527. Idem, p. 86 . 
datam de 1920, enquanto a primeira versão da peça surge entre 1924 e 1928 e tem sua estréia em 1928, na Volksbühne de Berlim, recebida com elogios da crítica, depois de uma pré-estréia também bastante elogiada em Darmstadt. ${ }^{15}$ Nessas duas primeiras fases de trabalho, a transformação de Galy Gay não é, em princípio, negativa. A montagem de 1931, porém, ressalta o caráter negativo do processo, apresentando a remontagem de Galy Gay como a construção de uma "máquina de guerra". Ao contrário das montagens anteriores, esta terceira versão da peça foi muito mal recebida, tendo apenas cinco apresentações e provocando a rejeição dos críticos de teatro, inclusive de Herbert Jhering, crítico importante na época e normalmente favorável ao trabalho de Brecht. ${ }^{16}$

A crítica de Jhering chama a atenção, em primeiro lugar, para o exagero e a disparidade no uso de instrumentos cênicos como pernas de pau, mãos gigantes e máscaras que desfiguravam os traços e as medidas corporais dos atores. $\mathrm{Na}$ análise de elementos específicos da encenação, ele crítica ainda a atuação de Peter Lorre no papel principal pela falta de nitidez de sua dicção e pelo caráter episódico de sua atuação. Estas restrições situam-se em exato contraste com sua avaliação da montagem de 1928 na Volksbühne, fortemente elogiada pelo uso conseqüente da técnica teatral ("Brecht não ataca, nem comemora a mecânica da era da máquina" ${ }^{17}$ ), pela nitidez da montagem e do trabalho de direção, assim como pelo desempenho do ator que interpretava Galy Gay. Em 1931, por sua vez, suas críticas pontuais à montagem se reúnem em torno de uma observação de ordem geral, que destaca a incompatibilidade entra a montagem e a própria concepção do teatro épico: Brecht teria demonstrado e defendido uma teoria utilizando um objeto rejeitado. Nos termos da peça: Brecht teria entrado em contradição com a tese da possibilidade de transformação emanci-

15. Cf. Knopf, J. (Hrsg.) Brecht-Handbuch I: Stücke. Stuttgart, Weimar: Metzler, 2003, pp. 152-4.

16. Jhering, H. "Vom Lustspiel zum Parabel. Skandal im Staatstheater". In: Von Reinhardt bis Brecht. Eine Auswabl der Theaterkritiken von 19091932. Hamburg: Rowohlt, 1967, p. 326. Suas críticas elogiosas às montagens anteriores de Um homem é um homem foram republicadas neste mesmo volume.

17. Jehring, H. Op. cit., p. 262. 
patória do homem, a qual sustenta um teatro pedagógico ligado às lutas sociais, ao apresentá-la num grupo social - o exército colonial inglês - que ele critica e ridiculariza com humor negro. Nas palavras de Jehring, teria sido um erro "provar um princípio épico num grupo dramático cuja visão de mundo é negada”. ${ }^{18}$

A julgar por esta reprovação, de modo algum uma reação isolada à peça, a crítica teatral da época não teve dificuldades em lidar somente com as inovações introduzidas na técnica de encenação, mas também com o endurecimento da crítica de Brecht ao comportamento dos soldados e à transformação militarista de Galy Gay. ${ }^{19}$ Se a historicidade do homem apresentava condições de superação do individualismo em função de uma nova relação com a coletividade, Brecht também julgou necessário chamar a atenção para o potencial de agressividade inscrito em toda formação do coletivo. Embora esta questão se intensifique somente na montagem de 1931, Patrick Primavesi, em seu verbete para o Brecht-Handbuch, observa que a questão da violência do coletivo contra o indivíduo já vinha sendo trabalhada desde os primeiros esboços. As sucessivas versões da peça demonstram a crescente relevância do problema para Brecht, que confronta a questão inicial do fortalecimento do indivíduo na massa com os problemas do marxismo e da ideologia de massa fascista, uma questão à qual ele retornaria até os anos 1950, quando recoloca o problema da peça como o da força sedutora exercida pelos falsos coletivos sobre o pequeno burguês..$^{20} \mathrm{~A}$ questão não dizia respeito somente à caracterização do exército colonial inglês como uma comunidade a-social, o que, de resto, não era grande novidade na época. ${ }^{21} \mathrm{O}$ que importava na parábola era, segundo Primavesi, o questionamento do modelo de comportamento apresentado. Por meio da ênfase nos aspectos grotescos, a guerra deveria ser mostrada como forma socialmente representativa de um crime legalizado. Na medida em que Brecht apresenta a integração do homem civil no exército como uma comédia cruel, ele

18. Idem, p. 327.

19. Cf. Knopf, J. (Hrsg.). Brecht-Handbuch I: Stücke. Stuttgart, Weimar: Metzler, 2003, p. 162; e Brecht-Handbuch IV: Schriften, Journale, Briefe, p. 59.

20. Knopf, J. (Hrsg.). Brecht-Handbuch IV: Schriften, Journale, Briefe, p. 58.

21. Cf. críticas à peça mencionadas por Primavesi em: Idem, p. 59. 
não obtém apenas uma descrição realista da guerra colonial. Com a apresentação da remontagem como um processo de iniciação que inclui a morte simbólica e o abandono da identidade anterior, ele demonstra, ao mesmo tempo, a dependência deste coletivo em relação à liberação de energias criminais, a-sociais e destrutivas. ${ }^{22}$

A crítica de Jhering deu ensejo à resposta imediata e pormenorizada de Brecht. Publicada pouco depois no mesmo jornal berlinense, ela constitui parte importante das "Anotações à comédia Um homem é um homem", um conjunto de textos que ressalta os procedimentos concretos empregados na montagem no contexto de uma nova forma de teatro. Ao confrontar seus críticos, Brecht reforça o caráter de parábola da peça pela ênfase na artificialidade pronunciada dos procedimentos. Com o intuito de demonstrar que o homem é uma construção artificial, Brecht, que assumiu pessoalmente a direção da peça, explorou a artificialidade dos adereços cênicos com o intuito de apresentar o "natural" como artificialmente produzido. A introdução de máscaras, pernas de pau e mãos gigantes assumia a função, pela descaracterização do corpo humano, de mostrar tanto as dimensões naturais do corpo quanto o rosto nu e sem máscara como um efeito artístico. É assim que o rosto nu do ator Peter Lorre é apresentado como uma etapa do processo de transformação: sua expressão não é um produto de emoções interiores de uma "personalidade", mas resultado de um processo teatral que as expõe na sua exterioridade. Algo semelhante ocorria com sua dicção: a fala sem entonação e nitidez buscava chamar a atenção do espectador para momentos específicos do texto. De maneira segmentada e na forma de estrofes, o objetivo não era envolver o espectador na contradição do discurso dramático, mas, como diz Brecht, afastar o espectador do texto, um efeito de distanciamento alcançado com a apropriação da noção de cesura de Hölderlin, cuja função não era a de ressaltar as representações no verso, mas o próprio trabalho poético de representação. Nesse sentido, o próprio texto era encenado do ponto de vista da sua interrupção, chamando a atenção para a artificialidade da fala natural.

22. Idem, ibidem. 
Esses elementos organizavam-se, por sua vez, no caráter de peça dentro da peça com que a exposição da transformação de Galy Gay era conduzida. Brecht segmentou as etapas e as circunscreveu com artifícios que chamavam a atenção para a especificidade de cada momento. Projeções forneciam os números das etapas da transformação, enquanto dois painéis mostravam ao fundo imagens de Galy Gay antes e depois de sua remontagem. Com a mesma finalidade, Peter Lorre buscava mostrar o emprego de um mesmo procedimento em situações distintas: Galy Gay se aproxima do muro com o mesmo gesto que repete depois, quando seu fuzilamento é encenado. Com isso, chamava-se a atenção do espectador para a conexão entre dois momentos distintos da ação, ressaltando a transformação ocorrida. Tratava-se, na formulação de Brecht, de exigir do espectador a postura de quem folheia um livro, ou seja, a percepção direcionada para a citação dos movimentos corporais no contexto de um processo de literalização do teatro que não ocorria pelo texto, mas pela relação diferenciada entre corpo e texto no contexto da transformação da ação.

Essa articulação entre natural e artificial dependia, porém, da constituição de uma relação diferenciada entre a exposição teatral e a conexão entre os processos apresentados. O enredo não deveria desenvolver-se teleologicamente rumo ao seu desfecho, como se poderia dizer da forma dramática canônica, mas interromper-se de modo que cada parte pudesse ser vista na sua singularidade. $\mathrm{O}$ realce dos elementos constitutivos salientaria a artificialidade do todo. Esta idéia de totalidade, como algo construído por partes independentes, é ressaltada diversas vezes nas "Anotações à comédia Um homem é um homem" com os conceitos de gesto fundamental (Grundgestus) e fluxo total (Gesamtfluß), empregados por Brecht na descrição do trabalho do ator épico. Assim como cada gesto corporal deveria obedecer a uma orientação de ordem geral, dada pelo gesto fundamental, o ator épico, diz ele, deveria lançar luz sobre determinados condicionantes dos processos históricos pelo modo como ele conecta procedimentos individuais e os insere no fluxo total de sua apresentação. Ao contrário do ator dramático, ele não tem desde o início seu personagem constituído, mas faz com que este apareça aos poucos, de maneira segmentada, diante dos 
olhos do espectador. Daí não resulta um personagem imutável, mas um outro que, em suas sucessivas mudanças, ganha nitidez para a platéia. Com isso, o teatro épico dissolveria a idéia do "ator portador da ação", ou seja, do ator que interioriza o papel principal de maneira unitária e sem interrupções.

De acordo com a descrição acima, os procedimentos empregados por Brecht na montagem de 1931 podem ser caracterizados como uma dialética entre partes e todo: a tendência à desagregação inscrita na separação dos elementos é contrabalançada por um movimento totalizador, responsável por garantir a coerência da parábola, de modo que o espectador pudesse realizar a síntese dos procedimentos apresentados, dela extraindo um ensinamento prático. Aos diversos elementos que chamam a atenção do espectador para os mecanismos mobilizados pela própria apresentação, Brecht julga ainda necessário sobrepor a autoridade do próprio dramaturgo com o intuito de garantir que o ensinamento não se perdesse na figuração. De maneira irônica, mas também professoral, ele surge na terceira pessoa, anunciando a doutrina que sustenta a peça. $\mathrm{Na}$ montagem de 1928 , ele aparece no interlúdio da viúva Begbick, que introduz a transformação de Galy Gay em outro homem, enquanto 1931 ele se antecipa à própria peça, introduzindo a questão já em seu prólogo:

O senhor Bertolt Brecht afirma: um homem é um homem.

$\mathrm{E}$ isso qualquer um pode afirmar.

Porém o senhor Bertolt Brecht consegue também provar

Que qualquer um pode fazer com um homem o que desejar.

Esta noite, aqui, como se fosse um automóvel, um homem será desmontado

E depois, sem que dele nada se perca, será outra vez remontado.

Com calor humano dele nos aproximaremos

E sem dureza, mas com energia, a ele pediremos

Que saiba às leis do mundo se conformar

$\mathrm{E}$ que deixe seu peixe tranqüilo nadar.

Não importa no que venha a ser transformado,

Para sua nova função estará corretamente adaptado. 
Mas, se não o vigiarmos, ele poderá se tornar

Da noite para o dia, um assassino vulgar.

O senhor Bertolt Brecht espera que observem o solo em que

pisam

Como a neve sob os pés se derreter.

E que, vendo Galy Gay, finalmente compreendam

Como é perigoso neste mundo viver. ${ }^{23}$

Um dos expedientes pedagógicos lembrados por Benjamin era a apresentação de situações já conhecidas, de modo que a atenção do espectador contemplasse também o modo como elas eram apresentadas. $\mathrm{O}$ anúncio prévio da remontagem de Galy Gay desempenha assim a função de preparar o espectador, transformando o processo em objeto de estudo. Desse modo, o prólogo se conecta também àquelas técnicas de literalização do teatro, como a construção de molduras textuais para determinadas cenas, por meio da projeção de legendas introdutórias a cada etapa da remontagem do estivador em soldado. Embora esse prólogo possa ser alinhado a tais formas de redimensionamento da relação entre texto e exposição, sua função central é assegurar a tradução da figuração artística em sentido transmissível ao público. Em outras palavras, Brecht parecia temer que seu ensinamento pudesse perder-se na irredutibilidade dos procedimentos de encenação ao sentido unívoco e certeiro, necessitando então da sobreposição das palavras do dramaturgo para garantir a eficácia da parábola. Diante destas questões, é plausível supor que partes e todo, ou melhor, procedimentos de encenação como a repetição dos gestos ou a cesura das falas, de um lado, e as intenções totalizantes inscritas na fábula, no gesto fundamental e no fluxo total, de outro, não compõem, como Brecht pretendia, uma unidade livre de tensões. A hipótese a ser explorada aqui é a de que o ensaio de Benjamin "O que é o teatro épico?" se movimenta no interior dessas tensões, voltando o teatro épico contra a intenção mais explícita de seu autor ao defini-lo como um teatro gestual.

23. Brecht, B. "Um Homem é um Homem". In: Teatro Completo, vol. 2. Trad. de Fernando Peixoto. São Paulo: Paz e Terra, 1991, pp. 181-2. 
A força pedagógica da peça - sua capacidade de mostrar ao público que o homem e as situações são históricas e modificáveis - não é apresentada por Benjamin a partir da posição explícita do dramaturgo, nem das muitas passagens em que os personagens comentam a encenação teatral como um processo de desmontagem e montagem de seus elementos. Nenhum desses expedientes possui a força e a evidência da repetição de um mesmo gesto em momentos-chave da peça. "O mesmo gesto faz Galy Gay aproximar-se duas vezes do muro, uma vez para despir-se e outra para ser fuzilado. $\mathrm{O}$ mesmo gesto faz com que ele desista de comprar o peixe e aceite o elefante". ${ }^{24}$ A pedagogia teatral não se efetiva pela assimilação da tese de que o homem pode ser diferente do que ele é, mas por meio do jogo, do exercício lúdico com os procedimentos teatrais e corporais de desmontagem e remontagem do homem. $\mathrm{Na}$ interpretação de Benjamin, esse processo de citação do gesto, longe de ser um elemento secundário na economia da montagem, eleva-se à posição de organizador da exposição e princípio formal decisivo do teatro épico.

A atenção de Benjamin às mediações entre a concepção de teatro épico e técnicas de encenação desenvolvidas por Brecht o leva a localizar o cerne da exposição teatral naquele elemento que lhe permite definir o teatro épico como um teatro gestual: a passagem da interrupção da ação à produção do gesto.

Em face das assertivas e declarações fraudulentas dos indivíduos, por um lado, e da ambigüidade (Vielschichtigkeit) e falta de transparência de suas ações, por outro, o gesto tem duas vantagens. Em primeiro lugar, ele é relativamente pouco falsificável, e o é tanto menos quanto mais imperceptível e habitual for esse gesto. Em segundo lugar, em contraste com as ações e iniciativas dos indivíduos, o gesto tem um começo determinável e um fim determinável. Esse caráter fechado, circunscrevendo numa moldura rigorosa cada um

24. Benjamin, W. "O que é o teatro épico?". In: Gesammelte Schriften, vol. II-2, p. 530. Edição brasileira: Benjamin, W. Obras Escolhidas, vol. I, p. 89. 
dos elementos de uma postura que, não obstante, como um todo, está inscrita num fluxo vivo, constitui um dos fenômenos dialéticos mais fundamentais do gesto. Resulta daí uma conclusão importante: quanto mais frequentemente interrompemos o protagonista de uma ação, mais gestos obtemos. ${ }^{25}$

Essa relação entre partes e todo é bastante distinta daquela descrita por Brecht em suas "Anotações à comédia Um homemé um homem". Em Brecht, a conexão da particularidade do gesto com a totalidade do fluxo total e do gesto fundamental era apresentada como uma figura do encadeamento da particularidade num todo contraditório compreendido como o sentido da parábola.

Pois se tratava aqui mais uma vez de destacar do sentido de cada frase um gesto fundamental bem determinado, o qual não podia prescindir inteiramente do sentido de cada frase para ser percebido, mas precisava ainda deste sentido somente como meio para atingir um fim. O conteúdo das partes consistia de contradições, e o ator tinha que tentar envolver o espectador nas próprias contradições, mas não por meio da identificação com cada frase, e sim mantendoo afastado delas. A apresentação teve de ser o mais objetiva possível, mostrando um processo interno cheio de contradições enquanto um todo. (...) $\mathrm{O}$ esforço do ator épico de chamar a atenção para determinados processos entre os homens (colocando os homens como o milieu) pode levar às vezes ao erro de entendê-lo como um episodista de fôlego curto caso não se considere como ele conecta todos os processos particulares uns aos outros, inserindo-os no fluxo total de sua apresentação. ${ }^{26}$

Benjamin, ao contrário, situa a conexão entre o gesto e o fluxo vivo sob a figura da interrupção, a qual não insere, mas destaca o gesto do fluxo vivo, impedindo o encadeamento da ação. Destacado da continuidade, o elemento desapercebido ganha o caráter de expositor da ação em que estava inserido. Seu caráter circunscrito - sua moldura - permite assim mostrar a articulação

25. Benjamin, W. “O que é o teatro épico?”. In: Gesammelte Schriften, vol. II-2, p. 521. Edição brasileira: Benjamin, W. Obras Escolhidas, vol. I, p. 80.

26. Brecht, B. "Anmerkungen zum Lustspiel Mann ist Mann". In: Schriften zum Theater, pp. 983-6. 
deste fluxo vivo. Seria esta sua relação com a verdade, seu caráter não falsificável: sua irredutibilidade a todo sentido previamente constituído como possibilidade de construção de novos sentidos.

A descoberta das circunstâncias, responsável por despertar o interesse do público, não é produto de uma explicação totalizante que revela ao espectador como o mundo funciona, mas da interrupção mesma do discurso. "A descoberta de situações se processa pela interrupção dos acontecimentos". ${ }^{27} \mathrm{~A}$ interrupção tem a função crítica de tornar estranha uma situação habitual, desmontando-a em seus componentes, e mostrando, a partir da possibilidade de um novo rearranjo, a falsidade do arranjo corrente. Sua função não é assim só de desmontagem, de destruição do contexto. Ela prepara os elementos para serem remontados em uma nova situação. Ela mostra tanto sua imprescindibilidade quanto sua insuficiência. Sua limitação está na incapacidade de passar da desmontagem à remontagem, uma vez que ela só imobiliza, decompõe, separa em seus elementos uma dada situação. Quem realiza a tarefa de remontagem é o gesto. "O teatro épico é gestual. (...) O gesto é seu material, e a aplicação oportuna desse material é sua tarefa. (...) quanto mais frequentemente interrompemos o protagonista de uma ação, mais gestos obtemos. Em conseqüência, para o teatro épico a interrupção da ação está no primeiro plano". ${ }^{28} \mathrm{~A}$ função da interrupção está na produção do gesto. A interrupção mostra a mutabilidade da situação por permitir que uma determinada situação se imobilize e seja desmontada, de modo que o gesto seja dela retirado e montado em uma nova situação.

A interrupção está colocada a serviço da citação do gesto, um processo que se origina na literalização do palco, por meio do qual o próprio texto é mobilizado no sentido da interrupção do elemento discursivo por excelência da apresentação teatral tradicional, o enredo. $\mathrm{Na}$ segunda versão do ensaio sobre o teatro épico, Benjamin afirma: "A interrupção é um dos procedimentos fundamentais de toda constituição da forma. Ela se fundamenta na citação: citar

27. Benjamin, W. "O que é o teatro épico?". In:__. Gesammelte Schriften, vol. II-2, p. 522. Edição brasileira: Benjamin, W. Obras Escolhidas, vol. I, p. 81.

28. Idem, p. 521. Edição brasileira: Idem, p. 80. 
um texto é interromper seu encadeamento (Zusammenhang)". ${ }^{29} \mathrm{~A}$ introdução de canções e cartazes rompe a identidade entre texto e enredo, suspendendo o curso da própria ação, ou seja, do próprio discurso que sustenta a apresentação. A citação mostra que uma nova ordenação dos elementos era uma possibilidade da situação original, ou seja, a citação é referência à pré-existência dos elementos na situação anterior, crítica da ordenação dessa situação anterior pela interrupção que a desmonta e passagem para uma nova organização, que mantém o arranjo anterior como um arranjo estranhado. Trata-se de uma crítica feita com a linguagem e com o material do objeto criticado, passagem, enfim, da destruição à construção.

\section{III}

Benjamin apontou a inscrição histórica do teatro épico ao afirmar que a articulação de gesto e interrupção na constituição de um teatro não-ilusionista não era uma utopia do dramaturgo, mas uma possibilidade histórica inscrita no estágio mais avançado da técnica. No ensaio de 1931, ele escreve: "As formas do teatro épico correspondem às novas formas técnicas, ao cinema e ao rádio. Ele está situado no ponto mais alto da técnica".$^{30} \mathrm{E}$ três anos depois, em 1934, em "O autor como produtor", a questão é recolocada do seguinte modo: "Com o princípio da interrupção, o teatro épico adota um procedimento que se tornou familiar para nós, nos últimos anos, com o desenvolvimento do cinema e do rádio, da imprensa e da fotografia. Refiro-me ao procedimento da montagem: pois o material montado interrompe o contexto no qual é montado". ${ }^{31}$ A destruição do teatro ilusionista pelas técnicas avançadas de montagem emprestadas do rádio e do cinema não é

29. Benjamin, W. "O que é o teatro épico?", $2^{a}$ versão. In: Gesammelte Schriften, vol. II-2, p. 536.

30. Benjamin, W. "O que é o teatro épico?". In: ___. Gesammelte Schriften, vol. II-2, p. 524. Edição brasileira: Benjamin, W. Obras Escolbidas, vol. I, p. 83.

31. Benjamin, W. "O autor como produtor". In:__. Gesammelte Schriften, vol. II-2, pp. 687-8. Edição brasileira: Benjamin, W. Obras Escolhidas, vol. I, p. 133. 
assim apenas um ponto importante da análise de Benjamin, mas a própria perspectiva materialista de sua análise.

É importante notar, contudo, que a relação entre crítica do ilusionismo teatral e desenvolvimento técnico não era, a princípio, nada óbvia, uma vez que, como lembra Brecht em seus textos teóricos da década de 1930, o responsável pela sofisticação dos procedimentos ilusionistas na história do teatro europeu havia sido justamente o aperfeiçoamento da técnica teatral. A exigência de naturalidade, nesse sentido, não se colocava para os dramaturgos da época de Shakespeare com a mesma força com que se colocaria, mais tarde, para aqueles da época de Goethe, por exemplo. Com essa observação, Brecht pretendia mostrar que a empatia não era um princípio absoluto, mas uma conquista técnico-artística de uma época em que ela exercia uma função socialmente progressista. "A empatia é o grande instrumento artístico de uma época em que o homem é a variável e seu meio é a constante. Só é possível identificar-se com aqueles que trazem a estrela de seu destino no próprio peito". ${ }^{32}$ De acordo com esta caracterização, o ator deveria representar seu personagem com tal poder de sugestão que o espectador sentiria e veria o mesmo que o personagem. Não cabe a ele discutir os sentimentos ou o comportamento do herói, mas apenas compartilhá-los, pois o comportamento deste seria, para o espectador, algo natural, e sua ação assumiria a aparência de um destino que não pode ser alterado. Em outras palavras, Brecht diz que só seria possível identificar-se com aquilo que não se transforma. O elemento central da crítica de Brecht à empatia é a caducidade deste procedimento:

Essa empatia (identificação), um fenômeno social que significou um grande progresso para uma determinada época histórica, é cada vez mais um obstáculo para o desenvolvimento posterior da função social das artes teatrais. A burguesia ascendente, que promoveu um desenvolvimento poderoso das forças produtivas com a emancipação econômica da personalidade individual, tinha interesse nessa identificação com sua arte. Hoje, quando a personalidade individual "livre" tornou-se um obstáculo ao desen-

32. Brecht, B. Schriften zum Theater, p. 300. 
volvimento posterior das forças produtivas, a técnica de identificação da arte perdeu seu direito. A personalidade individual teve de abandonar sua função nos grandes coletivos, o que ocorre com difíceis lutas diante de nossos olhos. ${ }^{33}$

No momento em que a função de sujeito histórico passa a ser desempenhada pelos movimentos sociais organizados, e não mais pelo indivíduo, a empatia se torna um procedimento artístico conservador. "Os processos decisivos entre os homens (...) encontram-se nos grandes coletivos e não são mais apresentáveis do ponto de vista do homem individual. $\mathrm{O}$ indivíduo está sujeito a uma causalidade extremamente complicada e só pode ser mestre de seu destino como parte de um coletivo forçosamente contraditório em si mesmo". ${ }^{34}$ Mas Brecht não quer apenas mostrar que o homem não é compreensível na sua auto-suficiência, como um ser imutável e isolado, pois não bastava apresentar no palco essa nova ordenação social por meio de formas tradicionais fundadas na abstração do indivíduo, nem pela adaptação delas aos processos coletivos. Este é o fundamento de sua crítica ao naturalismo. Ainda que este tenha dado o impulso inicial na revisão do teatro tradicional, ele fora incapaz de promover uma transformação do teatro à altura das necessidades e possibilidades inscritas no material que pretendia apresentar. Diante da exigência de retratar a nova realidade da classe trabalhadora, o drama naturalista tornou visível sua "tendência à decomposição", fruto da introdução de elementos de natureza épica numa forma ainda estruturada segundo as restrições da forma dramática..$^{35}$

33. Idem, pp. 244-5.

34. Idem, p. 274.

35. Sobre essa "tendência à decomposição" do drama naturalista, cf. Szondi, P. Teoria do Drama Moderno. Trad. de Luiz Repa, São Paulo: Cosac \& Naifi, 2001. O esquema teórico decisivo do drama naturalista - a noção de meio - é de natureza épica, como indica sua origem no romance. Para Benjamin, em virtude da ausência de reflexão sobre a própria forma teatral, o objetivo naturalista de retratar a realidade não conseguiu abandonar o domínio do teatro ilusionista. Cf. Benjamin, W. "O que é o teatro épico?". In: Gesammelte Schriften, vol. II-2, p. 522. Edição brasileira: Benjamin, W. Obras Escolbidas, vol. I, p. 81. 
A "exposição correta do mundo" ${ }_{36}$, nos termos em que Brecht coloca o problema, exigia a transformação das formas de exposição tradicionais de modo que o teatro se transformasse num instrumento de conhecimento da realidade. O verdadeiro conhecimento das coisas, a que o teatro épico almeja, é produzido quando estas são expostas do ponto de vista da possibilidade de sua transformação. Mas isto não significa a adoção de uma posição utópica, pois essa transformação do teatro e da realidade não é uma idéia do artista, e sim uma possibilidade concreta inscrita no estágio mais avançado das forças produtivas. É este reconhecimento da correlação entre técnica e emancipação que permite a Brecht dar um encaminhamento não-ilusionista ao desenvolvimento da técnica teatral. Por isso, seu caminho não é o do excesso, da sofisticação que sobrecarrega o teatro tradicional com máquinas complicadas, inúmeros figurantes e efeitos refinados sem transformá-lo em seus fundamentos e potencializar o seu caráter ilusionista, tal como era observado no teatro comercial da República de Weimar. O caminho reconhecido por Benjamin no teatro de Brecht é o caminho da sobriedade, que se traduz no despojamento do palco de todo artifício supérfluo de modo a incorporar os mecanismos de montagem trazidos do rádio e do cinema.

(...) um teatro que, em vez de competir com esses novos instrumentos de difusão, procura aplicá-los e aprender com eles, em suma, confronta-se com esses veículos. O teatro épico transformou esse confronto em coisa sua. É o verdadeiro teatro do nosso tempo, pois está à altura do nível de desenvolvimento hoje alcançado pelo cinema e pelo rádio. Para fins desse confronto, Brecht limitouse aos elementos mais primitivos do teatro. Num certo sentido, contentou-se com uma tribuna. Renunciou a ações complexas. ${ }^{37}$

Trata-se da elaboração de um outro ponto de vista, a partir do

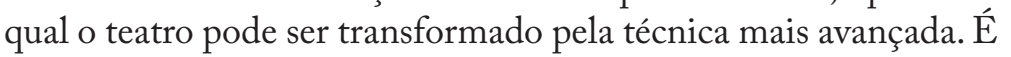
como se o teatro tivesse que livrar-se de todo adereço desnecessário, retornando, num gesto de despojamento sóbrio, à sua estrutura

36. Brecht, Schriften zum Theater, p. 306.

37. Benjamin, W. "O autor como produtor". In:___. Gesammelte Schriften, vol. II-2, p. 697. Edição brasileira: Benjamin, W. Obras Escolbidas, vol. I, pp. 132-3. 
básica, para só então começar de novo. "A tarefa mais urgente do escritor moderno: chegar à consciência de quão pobre ele é e de quanto precisa ser pobre para poder começar de novo". ${ }^{38}$ Não se trata aqui, evidentemente, de representação da pobreza, mas de um novo arranjo de elementos para a exposição da realidade. $\mathrm{O}$ despojamento do teatro de Brecht não é, assim, contraditório com a técnica mais avançada, mas é justamente a maneira mais conseqüente de incorporá-la como instrumento crítico-pedagógico.

As "Anotações à comédia Um homem é um homem" introduziam esta correlação entre teatro pedagógico e aparato técnico por meio da separação dos elementos que compunham o espetáculo, de modo que eles pudessem se realçar reciprocamente. O que Brecht formularia teoricamente nos anos de exílio como crítica à empatia do teatro aristotélico já se efetivava na série de interrupções da ação provocada pela montagem do material de origem diversa: canções, cartazes, projeção de textos, imagens e filmes. Se a introdução no palco desse material de procedência diversa permitia ao dramaturgo solidarizar-se com outros produtores, no sentido apontado por Benjamin em "O autor como produtor", e romper com o modelo de produção individual, a orientação da montagem pela interrupção da ação separa esses elementos e os mostra na sua independência, produzindo efeito contrário ao ilusionismo que domina em concepções como a da "obra de arte total":

Quando o construtor de palcos se une ao diretor, ao escritor de peças, ao músico e ao ator, o que diz respeito ao trabalho social da apresentação, cada um deles apóia os demais e goza desse apoio, e de modo algum esse trabalho precisa descambar numa "obra de arte total”, numa fusão total dos elementos artísticos. De certo modo, ele mantém, na sua associação com outras artes, por meio da separação de elementos, a individualidade de sua arte, do mesmo modo como ocorre com as outras artes. A colaboração entre as artes torna-se algo vivo; a contradição dos elementos não se dissolve. ${ }^{39}$

38. Idem, p. 695. Edição brasileira: Idem, p. 131.

39. Brecht, B. Schriften zum Theater, pp. 440-1. 
O único modo de evitar a produção da ilusão e da empatia é manter a independência e a contradição entre os elementos que compõem o espetáculo. Os efeitos produzidos pelo aparato cênico, musical e de iluminação, por exemplo, não devem desaparecer na ação, mas vir à tona como elementos distintos. Aqui o teatro épico se apropriava dos procedimentos de montagem do rádio e do cinema.

Se o cinema impôs o princípio de que o espectador pode entrar a qualquer momento na sala, de que para isso devem ser evitados os antecedentes muito complicados e de que cada parte, além do seu valor para o todo, precisa tem um valor próprio, episódico, esse princípio tornou-se absolutamente necessário para o rádio, cujo público desliga a cada momento, arbitrariamente, seus altofalantes. O teatro épico faz o mesmo com o palco. ${ }^{40}$

A técnica de montagem é incorporada então ao teatro como produto de sua reflexão sobre o próprio espetáculo enquanto algo produzido. A função social dessa postura se mostra no esforço em transmitir ao espectador o ensinamento de que também a realidade é algo construído e que poderia ser transformado com um novo arranjo de seus componentes. $\mathrm{O}$ que determina o avanço do processo que se desdobra no palco não é, portanto, a necessidade inscrita desde o início na ação e que a impulsiona em direção à resolução, mas um processo intermitente de montagem e desmontagem de situações. Quando o desencadeamento é interrompido e o caráter episódico da parte se torna evidente, não é a realidade mesma que aparece para o público, mas uma "ordenação experimental da realidade" ${ }^{11}$ cuja função é evidenciar o caráter histórico da situação encenada, por mais banal ou cotidiana que ela seja. $O$ exemplo preferido por Benjamin para ilustrar esse processo é o de uma cena de família.

Mostrarei, com um exemplo, como em sua seleção e tratamento dos gestos Brecht limita-se a transpor os métodos da montagem, decisivos para o rádio e para o cinema, transformando um artifício

40. Benjamin, W. “O que é o teatro épico?”. In: Gesammelte Schriften, vol. II-2, p. 524. Edição brasileira: Benjamin, W. Obras Escolhidas, vol. I, p. 83.

41. Idem, p. 522. Edição brasileira: Idem, p. 81. 
frequentemente condicionado pela moda em um processo puramente humano. Imaginemos uma cena de família: a mulher está segurando um objeto de bronze, para jogá-lo em sua filha; o pai está abrindo a janela, para pedir socorro. Nesse momento, entra um estranho. A sequiência é interrompida; o que aparece em seu lugar é a situação com que se depara o olhar do estranho: fisionomias transtornadas, janela aberta, mobiliário destruído. Mas existe um olhar diante do qual mesmo as cenas mais habituais da vida contemporânea têm esse aspecto. É o olhar do dramaturgo épico. ${ }^{42}$

O elemento casual, que normalmente passa despercebido, perde sua obviedade e se transforma em objeto de estudo para o espectador. A interrupção da ação é assim o princípio formal épico que combate o ilusionismo num movimento de mão dupla: os diversos elementos são introduzidos com a finalidade de interromper a ação e é a interrupção da ação que permite mostrá-los interligados, mas independentes entre si. $\mathrm{O}$ efeito de estranhamento, peça-chave da teoria do teatro épico, é, para Benjamin, uma conseqüência da produção de gestos pela interrupção da ação. Ela é a responsável pelo processo de "descoberta das condições" que se realiza sobre o palco e, assim, o elemento em torno do qual se configura a função pedagógica do teatro épico. ${ }^{43}$

$\mathrm{Na}$ medida em que o gesto aparece na interrupção da ação, ele é um produto da introdução no teatro das técnicas de montagem do rádio e do cinema e, consequentemente, o ponto de interseç̧ão do corpo com a técnica teatral. Ao apresentar a transformação da exposição teatral pela técnica por meio da citação de gestos, Benjamin mostra que o significado do gesto reside nessa

42. Benjamin, W. "O autor como produtor". In: _. Gesammelte Schriften, vol. II-2, p. 698. Edição brasileira: Benjamin, W. Obras Escolbidas, vol. I, pp. 133-4.

43. "Títulos que se antepõem às cenas, a fim de que o espectador possa passar do 'o que' ao 'como'; projeções que contrastam com os processos sobre o palco; o descobrimento do aparato de iluminação e da música; o estranhamento de todo cenário 'conhecido', o qual o torna saliente novamente em seu significado social; tudo isso confere ao espectador aquela postura desejada da consideração realista, que num mundo de premeditada confusão, tem tanta necessidade do conceito de falsificação consciente e inconsciente dos sentimentos". Brecht, B. Schriften zum Theater, pp. 464-5. 
exposição da fragmentação do movimento do corpo pela técnica. Como diz Patrick Primavesi, o "ator enquanto portador da ação dramática é suprimido (de modo experimental). No seu lugar entra o gesto montado". ${ }^{44}$ Com isso, Brecht teria trazido a exposição das contradições sociais para o corpo do homem. O conflito não é interiorizado nem psicologicamente resolvido, mas exposto na materialidade do corpo. Nesse processo, ou melhor, nesse jogo do corpo com a técnica se torna possível pensar uma relação de aprendizado entre o homem e o aparelho orientada pela possibilidade de o homem transformar-se de acordo com as circunstâncias. A idéia básica é a de que seu destino não se encontra traçado em sua personalidade, mas se decide no confronto com as contradições objetivas das situações em que toma parte..$^{45}$

É essa exposição do confronto entre o homem e a técnica pela fragmentação do movimento corporal que determina, por fim, a educação do ator brechtiano. "No teatro épico, a educação de um ator consiste em familiarizá-lo com um estilo de representação que o induz ao conhecimento; por sua vez, esse conhecimento determina sua representação não somente do ponto de vista do conteúdo, mas nos seus ritmos, pausas e ênfases". ${ }^{46} \mathrm{Ou}$ seja, o conhecimento está relacionado não só à interpretação da ação, aos elementos discursivos que se unificam no enredo, mas, sobretudo, aos momentos

44. Primavesi, P. Übersetzung, Kommentar, Theater in Walter Benjamins frühen Schriften. Frankfurt, Basel: Strömfeld Verlag, 1998, pp. 367-8.

45. Por isso, Galy Gay é chamado de o "homem que não sabe dizer não". Contra os dramaturgos que "atacam de fora as condições em que vivemos, Brecht as deixa criticarem-se mutuamente, de modo altamente mediatizado e dialético, contrapondo logicamente uns aos outros os seus diversos elementos. Seu estivador, Galy Gay, em Um homem é um homem, oferece o grande espetáculo das contradições da nossa ordem social. Talvez não seja excessivo definir o sábio, no sentido de Brecht, como o indivíduo que nos proporciona o espetáculo mais completo dessa dialética. De qualquer modo, Galy Gay é um sábio. (...) No entanto, é apresentado como um homem 'que não sabe dizer não’. Isso também é sábio. Pois com isso ele deixa as contradições da vida onde em última análise elas têm que ser resolvidas: no próprio homem. Só quem está 'de acordo' tem oportunidade de mudar o mundo". Benjamin, W. "O que é o teatro épico?”. In: ___. Gesammelte Schriften, vol. II-2, p. 526. Edição brasileira: Benjamin, W. Obras Escolbidas, vol. I, p. 85.

46. Idem, pp. 528-9. Edição brasileira: Idem, 87. 
gestuais que suspendem o curso da ação, transformando-a também em objeto da exposição. "O ator deve mostrar uma coisa, e mostrarse a si mesmo. Ele mostra a coisa com naturalidade, na medida em que se mostra, e se mostra na medida em que mostra a coisa". ${ }^{47}$ Uma vez que são os princípios técnico-formais do teatro épico que the conferem esta possibilidade, é possível dizer também que ele mostra a si mesmo na medida em que é mostrado pelo aparelho. $\mathrm{O}$ ator atinge assim o fundamento pedagógico decisivo do teatro épico: o que mostra deve ser mostrado. Em torno deste princípio se organiza a função pedagógica do teatro épico, segundo Benjamin. Ao impedir a identificação entre exposição e exposto, atraindo a atenção do público para o caráter construído da obra e das situações apresentadas, esse modo de exposição rompe com o ilusionismo da prática teatral. Como coloca Primavesi,

A construção desse momento indica que o gesto no teatro épico (...) exerce a função central de mostrar a exposição como tal, ainda independente de declarações morais ou de visão de mundo. Do mesmo modo como nas narrativas de Kafka, os gestos do teatro épico não têm 'nenhum significado simbólico assegurado' e permanecem dependentes da respectiva ordenação experimental. ${ }^{48}$

Como o gesto não é redutível a um significado preciso, mas é a própria apresentação gestual de abertura do sentido, a função pedagógica do teatro se efetiva como precedência da exposição em relação ao sentido fixo e determinado. Como diz Hans-Thies Lehmann,

O teatro não 'diz' outra coisa e não diz de forma alguma mais que o real, também não diz antes, ele não 'traz nada' no sentido de um aprendizado de novas intenções mentais. Ele produz, isso sim, uma tradução do mental no gestual. (...) Apenas para situar a teoria do gesto, isto não é algo como uma exposição sensível-corporal de um 'significado' social, mas a exposição gestual da abertura de sentido. O que Brecht ressaltou no gesto era seu caráter enigmático irredutível e não aquilo que o aproximava de outros procedimentos teatrais ou discursivos. 'Para organizar suas idéias, o pensador lê um livro que ele já conhece. Ele pensa no modo como o livro é

47. Idem, p. 529. Edição brasileira: Idem, p. 86.

48. Primavesi, P. Op. cit., pp. 369-70. 
escrito'. Este é o modelo de leitura do teatro. Poderíamos traduzir isso assim: 'Para organizar suas idéias políticas, o público toma parte num jogo gestual e lingüístico que ele já conhece. Ele pensa no tipo e o modo da exposição gestual e lingüística do processo. ${ }^{49}$

Aprender com o teatro implica entender que o jogo tem prioridade em relação à inteligibilidade mesma da ação. Não há, portanto, nenhum sentido trazido para a apresentação, mas somente o sentido que é inventado pela primeira vez no teatro. A recusa à determinação prévia do jogo por um sentido prévio não é só um modo de chamar a atenção para a exposição, mas também uma maneira de promover o exercício com o aparelho teatral, pois a encenação não é só representação da realidade, mas, antes de tudo, jogo com os procedimentos de representação.

Esse primado da exposição impede que o espectador se identifique com a ação e, portanto, que seja induzido a avaliar a transformação do homem em máquina de guerra como correta. $\mathrm{O}$ espectador deve parar para refletir sobre os procedimentos em curso. Brecht mostra a remontagem do homem como um processo correlato à técnica moderna, mas mostra seu lado destruidor em função da ação militar e da anulação da subjetividade perante o falso coletivo. $\mathrm{O}$ público não deve concluir que tal remontagem é positiva, mas que as condições sociais que destruíram a personalidade como essência individual imutável produziram uma máquina de guerra integrada ao falso coletivo, e também poderiam produzir outra. A questão, portanto, é mostrar uma possibilidade concreta - o homem pode ser transformado - e criticar uma modalidade de efetivação dessa possibilidade. Brecht se apóia assim na conquista do fim da personalidade burguesa para criticar seu desdobramento imperialista em máquina de guerra, reservando espaço para outro desdobramento fundado na historicidade do homem. Nesse sentido, o fortalecimento da crítica ao resultado da remontagem nas sucessivas versões não contradiz a idéia de remontagem como possibilidade histórica vislumbrada no teatro épico, mas enfatiza a historicidade do processo.

49. Lehmann, H-T. "Versuch über Fatzer". In: Das Politische Schreiben. Essays zu Theatertexten. Berlin: Theater der Zeit, 2002, pp. 252-3. 
Não por acaso, foi no teatro épico que Benjamin apontou, pela primeira vez, a figura de uma dialética em suspensão:

A condição descoberta pelo teatro épico é a dialética em suspensão. (...) no teatro épico a matriz da dialética não é a seqüência contraditória de palavras e ações, mas o próprio gesto. (...) Quando o fluxo real da vida é represado, imobilizando-se, essa interrupção é vivida como se fosse um refluxo: o assombro é esse refluxo. $\mathrm{O}$ objeto mais autêntico desse assombro é a dialética em suspensão..$^{50}$

Compreender o teatro como exposição dessa dialética em suspensão significa apontar sua função pedagógica em exercícios de interrupção e desmontagem de processos e situações e não na transmissão de um saber positivo a respeito da realidade. Em outras palavras, a pedagogia está no reconhecimento de possibilidades históricas vislumbradas no caráter experimental da citação de gestos. $\mathrm{O}$ fato de esse procedimento não se resolver na exposição da ação revolucionária - esta seria o horizonte político do teatro épico - significa que a experiência revolucionária ainda inédita não pode apresentar-se no palco. Por isso, em Um Homem é um Homem sua possibilidade surge sob a forma da desmontagem e da remontagem do homem como evidência de adaptabilidade à situação histórica que a ele se impõe. A única forma de exposição da política é a exposição da interrupção de todo processo no corpo do homem, desnaturalizando a situação histórica presente e garantindo a abertura de sentido ao próprio presente. Pois Brecht não poderia apresentar no palco a figura do herói ou do coletivo revolucionário, antecipando-se à experiência histórica que deveria produzi-lo. A dialética em suspensão deve ser vista como sinalização de um limite não ultrapassável pela exposição artística. O teatro permanece teatro: não se transforma em teoria da revolução, nem se funde com a política revolucionária.

\section{BIBLIOGRAFIA:}

BENJAMIN, W. Obras Escolhidas I. São Paulo: Brasiliense, 1995.

50. Benjamin, W. "O que é o teatro épico?”. In:__. Gesammelte Schriften, vol. II-2, p. 531. Edição brasileira: Benjamin, W. Obras Escolhidas, vol. I, p. 89-90. 
Gesammelte Schriften VI. Frankfurt am Main: Suhrkamp, 1999.

BRECHT, B. Schriften zur Theater. Frankfurt am Main: Suhrkamp, 1967.

Um Homem é um Homem. In . Teatro Completo 2. Trad. de Fernando Peixoto. São Paulo: Paz e Terra, 1991.

JEHRING, H. "Vom Lustspiel zum Parabel. Skandal im Staatstheater". In:__. Von Reinhardt bis Brecht. Eine Auswabl der Theaterkritiken von 1909-1932. Hamburg: Rowohlt, 1967.

KNOPF, J. (Hrsg.) Brecht-Handbuch. Stuttgart, Weimar: Metzler, 2003.

LEHMANN, H.-T. "Versuch über Fatzer". In:

. Das Politische Schreiben. Essays zu Theatertexten. Berlin: Theater der Zeit, 2002.

MÜLLER, H. "Fatzer \pm Keuner". In: KOUDELA. I. (org.). O espanto no teatro. São Paulo: Perspectiva, 2003.

PRIMAVESI, P. Übersetzung, Kommentar, Theater in Walter Benjamins frühen Scbriften. Frankfurt, Basel: Strömfeld Verlag, 1998.

ROSENFELD, A. O Teatro Épico. São Paulo: Perspectiva, 2002.

SCHWARZ, R. "Altos e Baixos da Atualidade de Brecht". In: Seqüências Brasileiras. São Paulo: Companhia das Letras, 1999.

SZONDI, P. Teoria do Drama Moderno. Trad. de Luiz Repa. São Paulo: Cosac \& Naifi, 2001.

WIZISLA, E. Benjamin und Brecht. Die Geschichte einer Freundschaft. Frankfurt am Main: Suhrkamp, 2004. 